\title{
Kunduz Market Assessment
}

Submitted by:

Chemonics International Inc.

Submitted to:

Afghanistan Mission,

U.S. Agency for International Development

Kabul, Afghanistan

August 2003

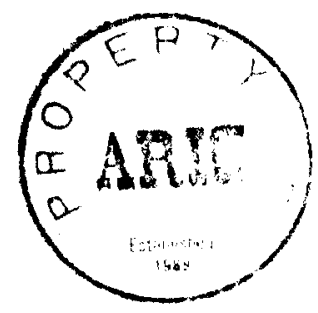

USAID Contract No. 306-C-00-03-00502-00 
TABLE OF CONTENTS I

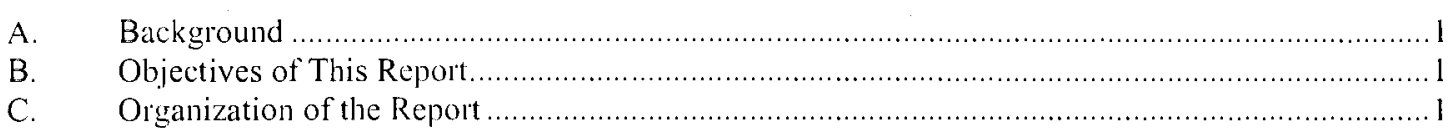

SECTION II - FINDINGS OF THE ASSESSMENT TEAM $\ldots \ldots \ldots \ldots \ldots \ldots \ldots \ldots \ldots \ldots \ldots$

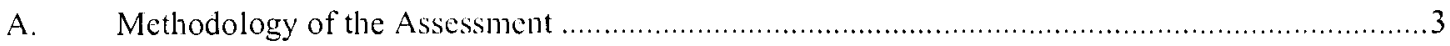

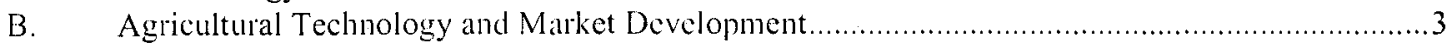

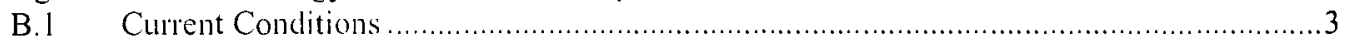

B.2 Participatory Rural Assessment of Local Markets ................................................. 7

B.3 Priorities of Kunduz Beneficiaries .................................................................

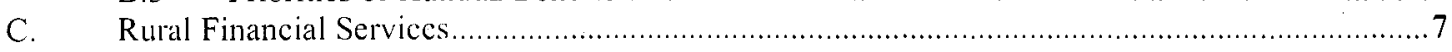

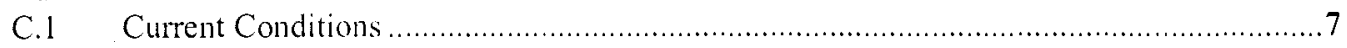

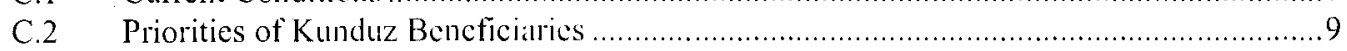

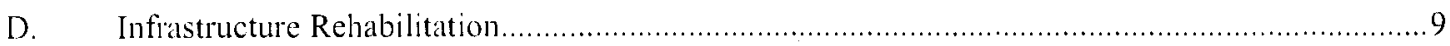

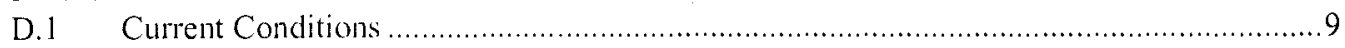

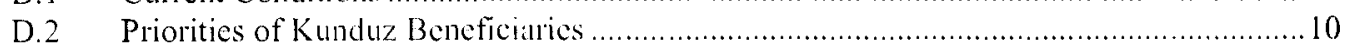

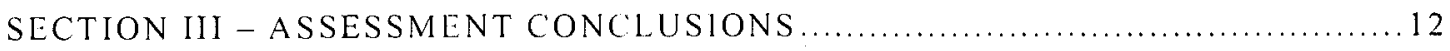

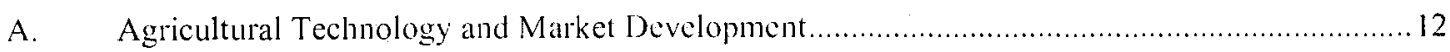

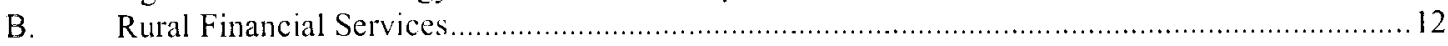

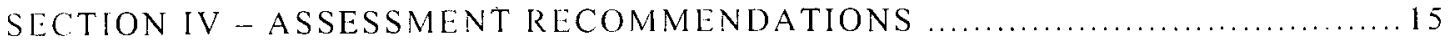

A. Agricultural Technology and Market Development...................................................15

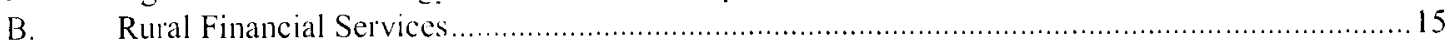

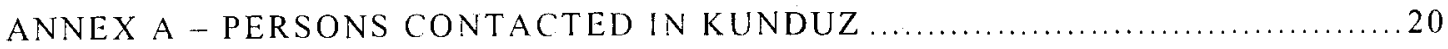

ANNEX B - KUNDUZ DEPUTY GOVENOR'S LETTER TO MAAH ................22

ANNEX C - SUMMARY OF PARTICIPATORY RURAL ASSESSMENT .............24

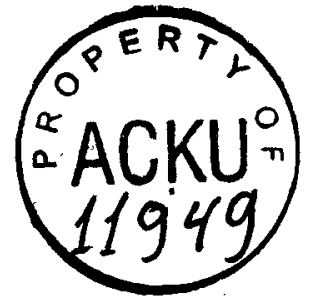


REBUILDING AGRICULTURAL MARKETS IN AFGHANISTAN PROGRAM (RAMP) 


\section{ASSESSMENT TEAM MEMBERS}

Dr. Larry Morgan

Dr. Ken Neils

Frances Toomey

Andy Hale

Mir Abdullha

Dr. Nasrat Wassimi

Dr. Nassiry
RAMP Chief of Party, Chemonics International

RAMP Chief Agricultural Strategist/Agricultural Economist, Chemonics International

RAMP Chicf Rural Financial Services Advisor, Shorebank Advisory Services

RAMP Monitoring and Evaluation Specialist, Chemonics International

Director, Seed Certification and Extension, Ministry of Agriculture and Animal Husbandry

Executive Program Manager/Afghanistan, International Center for Agricultural Research in Dry Areas (ICARDA)

Consultant, Food and Agriculture Organization of the United Nations 
REBUILDING AGRICULTURAL MARKETS IN AFGHANISTAN PROGRAM (RAMP) 


\section{LIST OF ACRONYMS}

FAO Food and Agriculture Organization of the United Nations

KRA Kunduz Rehabilitation Agency

MAAH Ministry of Agriculture and Animal HusbandryU.S. Department of Agriculture

RAMP Rebuilding Agricultural Markets in Afghanistan Program

REFS Rehabilitation of Economic Facilities and Services

TISA Transitional Islamic State of Afghanistan

UN United Nations

UNOPS United Nations Office of Project Services

USAID United States Agency for International Development 
REBUILDING AGRICULTURAL MARKETS IN AFGHANISTAN PROGRAM (RAMP) 


\section{EXECUTIVE SUMMARY}

RAMP is conducting market assessments in priority regions to identify the market structure for key commercial clusters that have high potential for increased competitiveness. The objectives of the market assessment in Kundu\% Province from August 5-7 (2003) were to assess the major commodity markets, identify key constraints to increased food security and rural incomes, and prioritize projects that can be implemented as RAMP job orders that serve to alleviate these constraints.

Market Assessments - Information gathered from Provincial and local Government leaders. farmers, traders, and processors, from a participatory rural assessment in five districts, and from observations of deteriorated road and irrigation infrastructure in the Provine formed the basis of the market assessment report for the Kunduz Province. The major commodity markets alssessed included wheat, rice, flax, salftower, almonds, cotton, melon, and selected other crops and livestock. Although the agricultural sector had a good production season, certain subsectors, including wheat, melons, and tomatoes, had marketing problems. A though the yicld and the total production of wheat, melons, and tomatoes in Kunduz Province rebounded very significantly from previous years' levels, market access remained a problem. Poor storage facilitics for grains and legumes resulted in a disproportionately high percentage of these commodities being sold soon after harvest. Consequently, lhe prices received by farmers for these commoditics (wheat $\$ 93 / \mathrm{mt}$, melons $\$ 35 / \mathrm{mt}$, and tomatoes $\$ 36 / \mathrm{mt}$ ) fell to levels nearing the farmers' cost of production.

Though rice is a major crop in Kunduz and production is expected to increase as irrigation facilities are repaired, much imported milled rice from Pakistan competes with the local rice. About $80 \%$ of the estimated total production of palddy rice was expected to enter the market soon after harvest with an estimated value of over 35 million dollars. Flax and safflower, produced in very modest amounts for oil and oilcake uses, have market potential since imported, nontraditional, palm oil represents a large percentage of the local market share. Almond production in Kunduz was estimated at over $7000 \mathrm{mt}$ with about $92 \%$ expected to be marketed with an estimated value of over 13 million dollars. Despite good growing conditions for cotton in Kunduz, market incentives for producing cotton remain muted because of the govermunent's controlled and below market prices and its ban on private ginning. Other crops with the most market potential include mung beans, fruits, and vegetables.

Small and large ruminant populations in Kunduz Province fell dramatically during the war and drought years and, more recently, from serious disease and parasites infestations. The livestock market in Kunduz is large and diverse and attracts livestock owners and traders from neighboring provinees.

Key constraints to increasing food security and rual income - Credit, irrigation and road infriastructure, and market aceess are the major constraints. Credit, short-, medium-, or long-term, from any formal financial institution is not available in Kunduz Province. Most of the irrigation systems are inoperable, many of the canals are heavily silted, and many of the water control gates (e.g., for the Khan Abad irrigation system) are damaged. The serious deficiencies in the Kunduz road system, including the temporary closing of the Salang tunnel for repair work) has led to sharp increases in transport costs and poor access to inter-regional markets. 
Project prioritization - To advanee the agricultural sector and improve agricultural incomes and marketing opportunities, the following is recommended:

- Road aceess from Kunduz to Kabul needs to be facilitated immediately; secondary and tertiary roads need to be improved in order to allow isolated villages better and cost effective access to Provincial markets

- Radio programs need to instituted that announce where and from whom improved seed, cost-effective, quality fertilizer, and effective agricultural chemicals are available

- Farmers need to be trained in the use of agricultural chemicals on their crops

- At least one demonstration plot needs to be established in each cluster of villages in all Districts to show farmers the production potential of improved varieties of major crops. such as, wheat, rice, and maize

- Provide water control and management training to mirabs responsible for extensive irligation schemes

- Provide technical assistance to farmers interested in installing greenhouses for vegetable production in the off season

- Farmers and traders need training in grain postharvest storage and handling. Grain storage (and drying) facilities that match the needs of farmers and traders need to bc identified and installed before the bulk of the rice is harvested

- Grain and legume cleaning and sieving equiment for farmers and traders need to made available on a custom basis

- The feasibility of modular wheat milling technologies, such as the Kice mill, needs to be made; if deemed feasible, investors for the milling equipment need to be identified

- The technical and cost efficiency of existing rice milling units needs to be determined and improvements in milling identified and implemented

- Equipment for dehusking and separating mong beans for increasing the value of the beans need to be identificl and the feasibility made

- Advocate for eliminating the government policy that limits cotton ginning to government owned gins

- Determine the feasibility of converting rice fields into fish farms

- Determine the feasibility of installing animal health laboratory facilities in the private sector

- Train and certify para-veterimarians in animal health, including vaccinating, discase and parasite control and treatment measures

- Establish private nurserics for vegetables, tree crops, and other trees for reforestation

- Establish an artificial insemination program through the MAAH and the para-vet program

- Solicit MISFA to work through their pre-selected microfinance institutions to identify an institution which would be able to locate in the Kunduz Province

- Allow Afghan and international NGOs to apply for a limited amount of loan capital to be on-lent to farmer associations and/or women's groups as a revolving loan fund.

- RAMP develops a guarantee fund mechanism through Afghan and international NGOs to be consignors or references for loans from a financial institution for the farmer associations and women's groups.

Because an Infrastructure Engineer was not on the RAMP Team, the project prioritization for infrastructure is not included. 
REBUILOING AGRICULTURAL MARKETS IN AFGHANISTAN PROGRAM (RAMP) 
REBUILDING AGRICULTURAL MARKETS IN AFGHANISTAN PROGRAM (RAMP) 


\section{A. Background}

Chemonics International is assisting the U.S. Agency for International Development and the Ministry of Agriculture and Animal Husbandry (MAAH) in the implementation of the Rebuilding Agricultural Markets in Afghanistan Program (RAMP) during 2003-200)6. The project aims to enhance food security and increase rural incomes in coordination with the MAAH's agricultural development policy and budget. RAMP has two main objectives: a) increased agricultural productivity and output, and b) increasing incomes through effective linkages between producers, processors and markets.

To increase productivity and output, RAMP will address constraints imposed by the lack of cash resources for productive activitics and deteriorated rural infrastructure. At the same lime, RAMP will initiate a rural infrastructure rehabilitation activities that would not be appropriate to carry out through either food for work or cash for work programs. To a lesser extent, the program also will support the expansion of the knowledge and use of improved technologies (new varieties, fertilizers, crop management and protection practices, equipment and machinery) through cxtensive field demonstrations, information dissemination, and efforts to develop the capacity of private sector input dealcrs to meet farm demand.

During the mobilization of RAMP, market assessments will be conducted in priority regions to identify the market structure for liey commercial clusters that have high potential for increased competitiveness. Results of these assessments will be used to design and implement technical assistance interventions that increase food security and rural income. A seven-member team (page iii) was assembled and deployed to Kunduz during August 5-9, 2003.

\section{B. Objectives of This Report}

The objectives of this report are:

1. Assessment of the major agricultural commodity markets and identification of key constraints to increased food security and increased incomes among rural families engaged in those markets: and

2. Identification of priority projects that can be implemented as RAMP job orders to increase access to agricultural technology, expand priority commodity and associated input markets, expand aceess to rural financial services and rehabilitate rural infrastructure.

\section{Organization of the Report}

Section II describes the findings of the Team in the areas of agricultural technology and marketing, rural financial serviecs and infrastructure rehabilitation.

Section III describes Team's conclusions, based on findings from interviews, available data and site visits.

Section IV describes the Team's recommendations for RAMP initiatives in Kunduz. 
Annex A lists the key Kunduz officials and cooperators contacted by the Team.

Annex B presents a letter from the Kunduz Deputy Governor to the Minister of Agriculture and Animal Husbandry, outlining the Kunduz Previncial Government's development prioritics for RAMP assistance.

Annex $C$ presents a summary of a participatory rural assessment was conducted in the five most populous districts by a survey team from Partners in Revitalization and Building (PRB) during
August 5-10,2003. 


\section{A. Methodology of the Assessment}

The team received generous assistance from the Kunduz Rehabilitation Agency (KRA), International Center for Agriculturil Research in Dry Areas (ICARDA) and the Food and Agriculture Organization of the United Nations (FAO) in arranging interviews and site visits.

The tean visited the provinicial governor's office and met with the Deputy Governor, His Excellency S.M. Daud. Also in attendance was the Kunduz President of Agriculture and Animal Husbandry, Mr. Haji M. Ebrahim, and Mr. H. Zubair, the President of Irrigation. An overview of the agricultural situation in Kunduz was given, as well as an overview of interventions needed to rehabilitate the agriculture sector and improve the livelihoods of agricultural populations. Improved access to markets was of primary concern, as increased production coupled with lack of accessibility to remote markets has diriven agricultural prices to levels below the cost of production in many cases. During an exit briefing on August 7, Deputy Governor Daud presented a list of development priorities for RAMP to consider in Kunduz. These priorities were included in a letter the Deputy Governor sent to the Minister of Agriculture and Animal Husbandry to emphasize the Kunduz provincial government's concerns about RAMP assistance (Annex B).

The remainder of the time was spent conducting interviews to obtain the development priorities of the local government, farmers and traders in various districts, and identifying and obscrving road and irrigation infrastructure inalequacies. Field trips were made to farms in Chahra Dara and Khan Abad districts, and the Khan Abad irrigation system. Wheat, rice and produce traters were interviewed in local markets and bazaars in Kunduz and Khan Abad. While the team collected these data, a participatory rural assessment was conducted in the five most populous districts by a survey team from Partners in Revitalization and Building (PRB). The results of this survey are summarized in Annex C.

\section{B. Agricultural Technology and Market Development}

\section{B.1 Current Conditions}

Kunduz is an agricultural surplus producing province in Afghanistan. Wheat and barley are planted in the fall and rice, mong beans, and vegetables may be planted in May-Junc following the wheat harvest. Maize, cotton, flax, melons, and watermelon are planted in the spring before the wheat is harvested. Although the agricultural sector has had a good production scason, certain sub-sectors are having marketing problems. Despite the abundant water resources in Kunduz, many irrigation facilitics are damaged, not functioning, and not supplying the water needed by producers for producing two crops per year.

\section{Wheat}

Wheat production in Kunduz in 2003 was estimated at approximately $360,000 \mathrm{mt}$ (averaging 3.2 $\mathrm{mt} / \mathrm{ha}$ ) on 100,000 hectares of irrigated land and 12,000 hectares of rainfed wheat in Kunduz (FAO, NCOA, 2003). Although yiclds are generally higher, many farmers are receiving less for their wheat than their cost of production (estimated by the MAAH at about Afs $7.6 / \mathrm{k}:$ (US\$ 
$157 / \mathrm{mt}$ ). The farmer, who transports the wheat to the marketplace (incurring as much as Ais $1.3 / \mathrm{kg}$ ), sells to the grain trader at a price approximately Afs $0.5 / \mathrm{kg}$ less than the trader's selling price.

The current trader's price of wheat in the Kunduz market varied from Afs $4.5 / \mathrm{kg}$ (US\$94/mt) for a poor quality of wheat to Afs $5.7 / \mathrm{kg}$ (US\$ $110 / \mathrm{mt}$ ) for a higher quality of wheat. It was observed that the grain trader often mixes the different qualities of wheat before selling. The depressed price for wheat in Kunduz is due to the increased production of wheat in Kunduz and also duc to poor roads and high transport costs to distant markets. The Kabul wheat market remains cut-off from the Kunduz farmers and traders because the tunnel on the Kunduz-Kabul road remains closed for repairs. However, higher wheat prices in Balakshan (over Afs $7 / \mathrm{kg}$ ) and Mazar (about Afs $6 / \mathrm{kg}$ ) has attracted from $50 \%$ to as much as $90 \%$ of the wheat that is entering the Kunduz and Khan Abad markets. The two markets are currently supplied with about $700 \mathrm{mt}$ and $175 \mathrm{mt}$, respectively, per week from the Kunduz markets.

Farmers and grain traders do not have adequate storage facilities for storing grains and legumes nor appropriate pesticides to control insect infestation. Consequently, postharvest losses are high and wheat quality decreases over time. The cost of storing grains or legumes in private storage in Kunduz is approximately Afs $30 / \mathrm{ml}$ per month, too expensive for most farmers.

Wheat is custom-milled with grinding stones powered by water or by diesel-powered wheat mills. No cleaning or sieving of the wheat is done before milling. Since the mill does not separate out the husk and the bran, the wheat yields $97 \%$ to $99 \%$ wheat flour. This results in a very poor, dirty flour. For this custom milling, the mill receives $1 \mathrm{~kg}$ of wheat for every $16 \mathrm{~kg}$ of
wheat milled.

Wheat farmers are concerned with accessing improved seeds and good quality fertilizer as the 2003 wheat planting season nears. In 2002-03, Mercy Corps worked with about 125 seed growers (with 4 to $10 \mathrm{ha}$ ) in producing about $15 \%(375 \mathrm{mt})$ of the wheat seed needed for the upcoming planting season in Kunduz. The wheat seed is expected to be processed in Mercy Corps' four processing centers and then sold to farmers. Some wheat farmers are, however, not aware of whether there will be a similar program as last year's IFDC's and ICARDA's program that provided improved seed and good quality fertilizer with repayment after harvest. Miny farmers are also not aware of where they can buy improved wheat seeds, despite the fact that there are many farmers in Kunduz who have produced certified wheat seed. Some Kunduz farmers do not trust the local fertilizer dealers for supplying good quality fertilizer. Their eoncern is not unfounded as fertilizer dealer's in Kunduz have been selling Turkminestan fertilizer "ammonia superphosphat", an inexpensive fertilizer (US\$ $6.7 / 50 \mathrm{~kg}$ ) with unmarked analysis (probably low in nitrogen and phosphate). USA and Pakistan made DAP fertilizer, which is selling for as much as three times more than the Turkminestan fertilizer, is not selling. Besides the Turkministan fertilizer for basal dressing, farmers are buying urea (US\$8.8/50kg) made in Mazar.

\section{Rice}

Because of the good rainfall and improved irrigation infrastructure, rice production in Kunduz is expected to be much higher this yeat than in past years. An estimated $231,000 \mathrm{mt}$ of rice produced on 77,000 hectares is expected to be produced in North-East Afghanistan (FAO, NCOA, 2003) in 2003. 
Rice can be planted following lhe production of wheat. Paddy farmers are expecting yiclds exceeding $5 \mathrm{mt} / \mathrm{ha}$. Some paddy has already been harvested in the Province. Once paddy is harvested, farmers either soak their paddy in water for about 10 days before drying it and then having it milled (costing $21 \mathrm{~kg}$ paddy $/ 100 \mathrm{~kg}$ paddy milled) at a diesel-powered mill or have it simply dehulled (costing $14 \mathrm{~kg}$ paddy/100 kg paddy milled) directly after harvesting. The farmers then transport the milled rice (long-grain) to the various markets in Kunduz. Province. Farmers are currently selling their milled rice to traders for Afs $18.6 / \mathrm{kg}$ to Afs $21.4 / \mathrm{kg}$ in the Kunduz and the Khan Abad markets. At these prices, the average farmer will be able to oblain a reasonable profit. Rice traders gencrally separate out the broken rice and sell the full-grain riee at a current price of Afs $21.4 / \mathrm{kg}$ to $\Lambda f s 5.7 / \mathrm{kg}$ and broken rice at about Afs $7 / \mathrm{kg}$. In addition to the local rice, full-grain, milled rice is imported from Pakistan and sold at prices similar to local rice. It is expected that when the bulk of the paddy has been harvested, much of it will be sold by traders in adjacent Provinces.

The area of paddy production is expected to increase in 2004 as more irrigated infiastructure is rehabilitated and more farmers produce paddy rice. To promote increased fertilizer elficiency in paddy production with large, slow-release, urea pellets, thirty-three paddy production demonstration plots were established (sponsored by USAID) in 2003 by IFDC and the Kunduz Rehabilitation Agency.

\section{Flax}

Flax is an important oilseed produced in Kunduz. Farmers have been selling their flax in the Kunduz market for about Afs $13.6 \mathrm{~kg}$. Traders sell the flax to local oil proeessers ( 11 in Kunduz) for about Afs $14.2 / \mathrm{kg}$. Processors extract the flax oil and sell it locally in drums for abour Afs $37 / \mathrm{kg}$. The processing of flax into oil seems to be highly profitable.

\section{Cotton}

Cotton is grown in Kunduz, however, the only operating gin in Kunduz is the Governmentowned, Spinzar cotton gin. The Spinzar cotton gin, however, ginned only $500 \mathrm{mt}$ of cotton in 2002.

\section{Melon}

A bumper melon and watemelon harvest reached its peak in August. Farmers in Kunduz produced 2000 to 3000 melons per hectare with fertilization. At this relatively high yickd, and at current prices of Afs $18-20 / \mathrm{mclon}$, farmers are able to make a reasonable profit in melons. However, much of the melons are trucked out the Province to Mazar and Balakshan. The largest market for the melons, the Kabul market, remains cut-off from the Kunduz melon farmers and traders. Transporting a truck of melons used to cost Afs 8,000 before the tunnel was closed, now the transport cost is 3 to 4 times that.

\section{Other Crops}

Maize, chickpeas, green mong beans, fruits and vegetables are also produced in varying quantities in Kunduz.

\section{Livestock}


Before the war, there were 800,000 to 1 million small and large ruminants in Kunduz Province. At that time, Kunduz had a substantial number of dairy cows and good dairy cow breeds. Since the war started, the population of small and large ruminants has declined, not only from the war and drought, but more recently from discase and parasites. There are no animal health laboratories in Kunduz and few livcstock owners are getting their animals vaccinated regularly The Kunduz livestock market is large and diverse and it attracts livestock owners and traders from adjacent Provinces. Most pcople selling their livestock in the market were selling thicir livestock to raise some cash to pay off dcbts and other family expenses.

\section{B.2 Participatory Rural Assessment of Local Markets}

A participatory rural assessment was conducted in the five most populous districts by a survey team from Partners in Revitalization and Building (PRB) during August 5-10, 2003. Five villages in each district were randomly selected and the local shoura collaborated with the survey team to identify a group of knowledgeable farmer and trader assessment participants. The villages and their locations are show'n in Figure 1. Each village PRA collected production and marketing data according to the formal shown in Annex C. Village crop and livestock production data (crop land and livestock populations) were aggregated and projected to the district level by the ratio of district cultivated land area (from FAO estimates) to the cultivate land area estimated in the five PRA villages. Village agro-enterprise and population data were aggregated and projected to the district level by the ratio of district population (Central Statistics Office 2003 data) to the populations estimated in the five PRA villages. The five district projections were aggregated to create the summary shown in Annex $C$.

Figure I. Location of Kunduz PRA Districts and Villages, August 2003

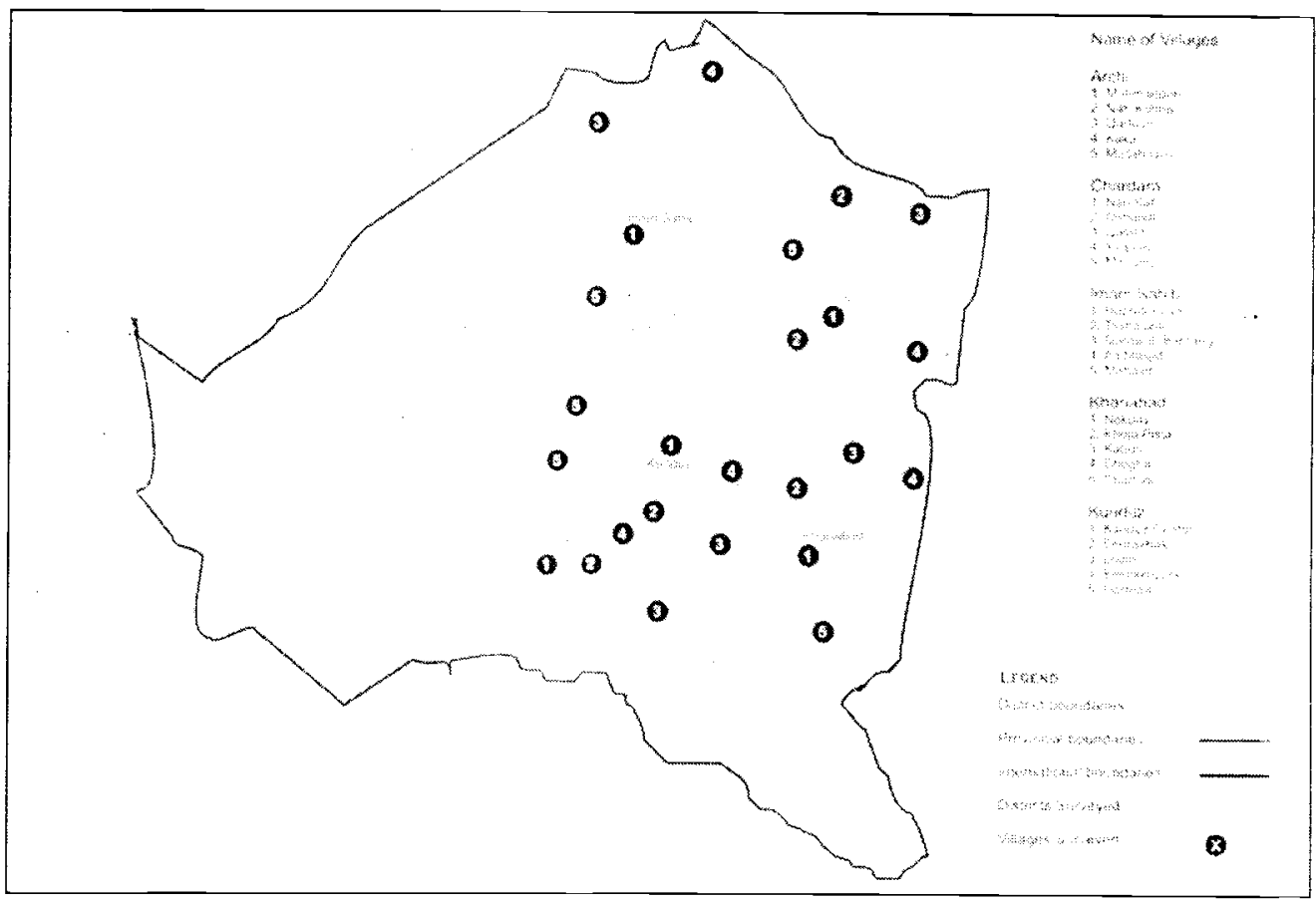




\section{B.3 Priorities of Kunduz Beneficiaries}

Kunduz famers, traders, processors, and others have a long list of needs and priorities, including:

- Improved seed for wheat, rice, legumes, vegetables and fruit (seedlings)

- Good quality fertilizer

- Access to credit for purchasing inputs and tractors

- Storage facilities for grains and legumes

- Access to credit for storage facilities

- Rehabilitating intakes, clcaning canals

- Training in more efficicnt irrigation water management for mirabs

- Improved vegetable secdlings

- Plastic greenhouses for raising crops

- Processing of fruits, vegctables, and milk

- Improved water harvesting and facilities for livestock

- Access to vaccines and disease and parasite control measures, animal health laboratories

- Artificial insemination program for large ruminants

- New dairy breeds

- Credit for purchasing small ruminants and dairy cattle

- Training and technical assistance in fish farming

\section{Rural Financial Services}

\section{C: 1 Current Conditions}

Currently, basic financial services from any formal financial institution are not available in Kunduz. Predominantly, Kunduz is based on a cash economy with very limited credit services and no facility for deposits of savings. According to one trader, hawalas do not exist in Kunduz for financial intermediation. Ally borrowings are transacted amongst suppliers, family and close friends. Generally, these are considered as delayed payments rather than loans and are slrortterm in nature with varying forms of interest payments. Examples of collateral provided lor these loans include personal references, land, livestock and equipment. Land titles are not registered or documented. Although, these items are not considered as traditional, reliable collateral because they are movable and not registered, they could deter the risk of defalult. Trust is the basis for many business deals; in fact handshakes seal the deal of many transactions. Some farmers in Kunduz have received credit from some fertilizer dealers through the IFDC fertilizer scheme. This scheme is to be phased out during the upcoming planting season yet some farmers are not aware of this program's termination.

A government managed women's resource center has been established in Kunduz with the assistance of USAID funding through CHLC, a local NGO. The center offers three lypes of training - traditional skill of carpet weaving, sewing and English language lessons. The women are trained and afterwards return to their homes or villages to utilize their new skills win income generating projects. The resource center had a list of requests for assistance including input materials for sewing, additional machines, button making machines and other inputs. The 
Deputy Governor expressed a desire to replicate these women's facilities in other districts within the province.

Some rural women earn income through carpet weaving which naturally involves a team of women to produce them. The production of carpets can take up to four months. Carpet weaving could be considered as an agricultural spin-off as the farmers with livestock are supplying the inputs of wool to make the yarn for the carpets. In addition, carpet weaving generates employment opportunities for primarily women.

Other women are individually scwing within their homes whilst their male family members sell their goods through the bazaar. There was a strong interest for credit to initiate small incomegenerating projects for women to do within their home compounds such as raising poultry, bakeries and tailoring.

The following are some observations based on an interview with a dozen sharecropping, landless farmers. They have limited resources, tend to collect and reuse seeds, band together theil products and transport them to distant markets for selling [except their close ncighbor Tajikistan as they do not hold passports so are unable to have cross-border trade opportunities], land is their only income, wives are not involved in income-generating activities and only do domestic work, utilize oxen for ploughing as they have no mechanization, receive $50 \%$ of the harvest fiom the landowner, all inputs must be paid by cash, they do not want to become indebted and would only borrow the equivalent of their land price.

Some of the traders in the market are selling their own fruits and vegetables. Others are selling produce on consignment for farmer's. The produce is sold within the local markets or transported 
to close districts. At the time of the assessment, there was no access to the Kabul markiets due to construction on the primary thorough road.

Based on the interviews conducted, there-was an unwavering demand for a supplier of credit both for short-term and long-term needs. The uses for these credits by the farmers include sceds, quality fertilizer, farm equipment, livestock breeding, greenhouses and storage facilitics. Some women groups have also expressed an interest in credit to support their livestock basedhandicrafts or to start income generating projects such as poultry rearing.

As a savings mechanism, farmers who have excess earnings generally reinvest them into the purchase of additional livestock, implements or other inputs. This is their approach to maintain and build wealth.

Of those we met, there is an inherent sense of community which could lend itself to peer group lending. Some farmers are already established as groups and have a bond of trust. They share a responsibility of supporting one another and band together to plant and harvest. In some groups, resources are pooled for the benefil of the community and profits are shared amongst the farmers. When a peer lending guarantee system was described to the farmers; they agreed with sharing the responsibility for repayment of each members loans. The farmers expressed that non-payers would be removed from the group.

Although defunct, the conditions and services of the Agricultural Development Bank were accepted by the traders and some firmers. This favorable impression bodes well for linancial institutions who will operate in the provinces as there was not an inherent distrust of banks. An NGO, Child Fund Afghanistan ${ }^{2}$, is operating in Kunduz and has provided loans to groups consisting of 5-10 members for income generating activities. Due to time constraints, the details of their lending activities could not be pursued.

This limited assessment did not permit a detailed analysis of the structure of the micro, small and medium enterprise sector in Kunduz. The information gathered for the current conditions of the market were based on interviews with various groups of farmers, women, landless farmers and traders. The assessment did conlim the importance of agricultural production and/or agricutural trade to the livelihoods of the majority of those interviewed. As most of those intervicived had only one source of income, their main income generating activity. This one activity, gencrally agriculture related, is the survival mechanism not only for the interviewee but their cxtended families which is considered an economic unit as part of a tradition within the Afghan culture.

\section{C.2 Priorities of Kunduz Beneficiaries}

\section{Infrastructure Rehabilitation}

\section{D.1 Current Conditions}

Kunduz province officials, farmers and traders consistently identified poor road and irrigation infrastructure as critical bottlenecks to crop production and marketing. During over lwo decades of war and lack of maintenance, most of the irrigation systems (irrigation structures, canals and

\footnotetext{
I Primarily for dairy cows, oxen, poultry and smill ruminants.

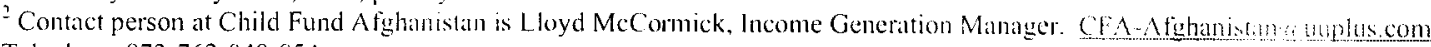
Telephone 873-762-048-854
} 
dams) are inoperable. Many of the water control gates are damaged from flooding or vandalism. Many of the canals are heavily silted.

The Kunduz Khan Abad irrigation system has been in disrepair for more than two decales. The initial survey and design was done by Water and Power Consultancy Services of India in 1975. The construction work was carried by the Helmand Construction Company of the Ministry of Water and Power of Afghanistan. Construction was halted in 1978 with about $90 \%$ of the project completed. In the intervening years, many of the canals have been filled with sill and most ropes, pulleys and gates have been damaged by floods or have been vandalized. The system has the following components:

- Head of Dam: It has 19 gates, most of which need repair or replacement.

- Right Canal: The canal is $8 \mathrm{~km}$ in length and about $8 \mathrm{~m}$ widc. A total of 14 gates control the flow and distribution of water for 15 secondary canals. All the gates need to be repaired or replaced. Sediment is about $2 \mathrm{~m}$ deep throughout most of the canal.

- Left Canal: This canal is $18 \mathrm{~km}$ in length and has an average width of about $15 \mathrm{~m}$. Sediment is about $1-1.5 \mathrm{~m}$ deep throughout most of the canal.

Restoring the system to full capacity would support about 25,000 ha of irrigated cropland.

A subsequent detailed assessment of the infrastructure situation in Kunduz was conducted by RAMP Eng. Ibrahim, and is currenty available.

The Chara Dara irrigation system has about $60 \mathrm{~km}$ of canals that need cleaning and repair. Restoring this system to full capacity would support about 32,000 ha of irrigated cropland.

The Kunduz road system has scrious deficiencies. While the Kunduz-Khan Abad primary road is in remarkably good condition and Mercy Corps has recently renovated sccondary roads in Chara Dara, the Alchin-Qalaizal secondary and tertiary roads in Chahar Dara and about $\mathrm{r}(3 \mathrm{~km}$ of secondary and tertiary in Khan Abad need grading and repair of bridges and culverts or upgrading to secondary status. However, the Baghlan road connecting Kunduz to Kabul is the province's strategic road bottleneck. This road is so damaged that loaded 10 ton trucks can casily suffer serious structural damage, even at very low speeds. These trucks face serious risk of tipping while navigating large potholes and diversions around damaged bridges and culverts. Most recently, Kunduz-Kabul road traffic has been futther disrupted by closure of the Salang tunnel for renovations.

These poor road conditions have contributed to sharp increases in transport costs.

\section{D.2 Priorities of Kunduz Beneficiaries}


REBUILDING AGRICULTURAL MARKETS IN AFGHANISTAN PROGRAM (RAMP) 


\section{SECTION III - ASSESSMENT CONCLUSIONS}

\section{A. Agricultural Technology and Market Development}

Productivity of Kunduz farmers increased dramatically in 2003, only to be offiset by higher farm labor costs, low crop prices, and poor access to distant markets, including Kabul. Livestock populations have been further reduced by the high incidence of disease's and parasites among small and large ruminants. For the agricultural sector to advanec and for farm family incomes to be increased, secondary and tertiary roads leading to marke centers for agricultural crops need to be repaired; better aceess to improved seeds of the major crops and good quality fertiliser needs to be made; farm plots demonstrating production of improved varietics of the major crops need to be established; irrigation . infrastructure needs to be rehabilitaled; grain/legume storage facilitics for both farmers and traders need to be identified and installed; credit opportunities need to be made available for production inputs, storige, processing, and marketing agricultural commodities; processing of grains, legumes, vegetables, and fruits need to be promoted: private cotton gins should be allowed to operate; rangeland needs to be improved through addition of catchments; animal health laboratorics, vaceines, and veterinary services need to be made readily available to the livestock industry, and an artificial insemination program needs to be implemented.

\section{B. Rural Financial Services}

Although financial services are not alvailable in the Kunduz market, it was not necessarily the first limitation mentioned. In face, acess to a suitable road infrastructure and quality seeds and fertilizer were generally the initial constraints expressed. However, access to credit would undeniably reduce the constraint of growth for promising enterprises. The current enterprises have not been able 10 grow through solely the reinvestment of any resulting profits.

Credit would allow farmers the capacity to purchase inputs, storage facilitics and equipment and manage their cash flow more efficiently. With access to credit women should regain some level of economic independence through their cconomic activities such as livestock-based handicrafts and small production such as poultry and bakeries. Also, some women have been left widows due to the last two decades of war and would benefit from credit as they currently do not have the a stable source of income. Credit for agricultural traders would permit them to increase their inventory with working capital loans.

Financial institutions could take advantige of pre-formed groups such as the farmers associations, developed by the ICARDA group. Afghan and international NGOs such als ICARDA and others could coordinatte with the financial institutions to identify potential borrowers who have the capacity to repay loans. These associations consist of farmers engaged in various activities such als grain farming, livestock breeding, fish farming and carpet weaving [operated by men bul produced by women].

Providing eredit for income generating projects performed by women would satisfy theit desire to have control over their own income. There is a sense that the women would be able to repay their debt as their skills are their livelihood and they have limited mobility. 
Financial institutions would have to consider the production time of women's projects such as carpet weaving, pouliry peojects or other aetivities when setting loan terms for this sector.

Lending to landless farmers will present a significant challenge to micro finance institutions (MFIs). They do not have any security to pledge and generally do not belong to farmers associations. Financial institutions will have to determine if there are any savings or loan products which may meet the needs of these individuals.

Short term credit could be provided to traders dealing with agriculture goods. These whort term loans could balance the loan capital disbursals of an MFI. An MFI would have io manage their capital to ensure they could lend both for short term and long term credit needs.

MFIs would need to develop loan products for these potential loan usages based on the different groups of borrowers - livestock, storage facilities, farm machinery, sewing machines, wool and other inputs for carpet weaving. RAMP could work with the MFis io share assessments and other in lormalion which could be used to develop their lending methodologies.

As the financial industry is just burgconing in Afghanistan, it will be essential for microfinance institutions and A fighan and international NGOs to coordinate and leverage their resources to identify credit worthy clients. An opportunity exists for MFIs to reach scale rapidly as currently there are not available credit sources for farmers, women, landless farmers and traders.

Typically, MFIs initially target urban micro and small enterprises. MFIs will have to determine their operational structure if they will locate in the urban centers and/or have a branch network. The potential for profitability would need to be examined as part of the MFIs strategic planning. It will be important for RAMP to convey to the donor community, the financial sector and investors that there is a demand for credit in the rural, agricultural sectors of Afghanistan. There should be a concerted effort by RAMP and inc other donors to campaign for MFls to reach the rural regions of the country.

\section{Infrastructure Rehabilitation}


REBUILDING AGRICULTURAL MARKETS IN AFGHANISTAN PROGRAM (RAMP) 


\section{SECTION IV - ASSESSMENT RECOMMENDATIONS}

\section{A. Agricultural Technology and Market Development}

To advance the agricultural sector and improve agricultural incomes and marketing opportunities, the following is recommended:

- Road access from Kundu\% 10 Kabul needs 10 be facilitated immediately; secondiry and tertiary roads need to be improved in order to allow isolated villages better and cost effective access to Provincial markets

- Radio programs need to instituted that announce where and from whom improved seed, cost-effective, quality fertilizer, and effective agricultural chemicals are available

- Farmers need to be trained in the use of agricultural chemicals on their crops.

- At least one demonstration plot needs to be established in each cluster of villages in all Districts to show farmers the production potential of improved varictics of major crops, such as, wheat, rice, and maize

- Provide water control and management training to mirabs responsible for extensive irrigation schemes

- Provide technical assistance to farmers interested in installing greenhouses for vegetable production in the off season

- Farmers and traders need training in grain postharvest storage and handling. Grain storage (and drying) facilities that match the needs of farmers and traders need to be identified and installed before the bulk of the rice is harvested

- Grain and legume cleaning and sieving equiment for farmers and traders need w made available on a custom basis

- The feasibility of modular wheat milling technologies, such as the Kice mill, needs to be made; if deemed feasible, investors for the milling equipment need to be identified

- The technical and cost efficiency of existing rice milling units needs to be determined and improvements in milling identified and implemented

- Equipment for dehusking and separating mong beans for increasing the value of the beans need to be identilied and the feasibility made

- Advocate for eliminating the government policy that limits cotton ginning to government owned gins

- Determine the feasibility of converting rice fields into fish farms

- Determine the feasibility of installing animal health laboratory facilities in the private sector

- Train and certify para-velerinarians in animal health, including vaccinating, discase and parasite control and treatment measures

- Establish private nurseries lor vegetables, tree crops, and other trees for reforcstation

- Establish an artificial insemination program through the MAAH and the para-ret program

\section{B. Rural Financial Services}

Financial services to agro-related entrepreneurs would only be feasible if there is a locilly based financial institution to provide this capacity. As there is not an existing financial instiution in 
Kunduz to provide financial services 10 the farmers, women's groups, traders and landless farmers, the following are possible alternative vehicles for delivery of rural finance. All of these potential delivery vehicles would need further analysis before implementing.

One possibility would be to bring to the attention of the MISFA (Micro Finance Investment and Support Facility) the unmet demand for eredit in the Kunduz region. We could solicit MISFA to work through their pre-selected microfinanee institutions (MFI) -- Agal Khan, AREA, BR. \(' CARE, CHF, FINCA, Mercy Corps, SCl: WOCCU, WfWI - to identify an institution which would be able to locate in the Kunduz provinee. Currently, Aga Khan and Mercy Corps are working in the province although their focus is not rural finance at this time. RAMP could share these assessment results of the area and assist in gathering population and density figures lon the MFI to demonstrate the sustainability of the institution to operate in this province. Also, the MISFA may be able to assist the MFI with a specific needs assessment of the potential clicntele composition for credit in the area.

Another probability is RAMP could allow Afghan and international NGOs to apply for a limited amount of loan capital to be on-lent to farmer associations and/or women's groups as a revolving loan fund. If this idea is pursucd, the NGOs would need some technical assistance on developing a sustainable, high quality credit scheme within their institutions.

Alternatively, RAMP could develop a guarantee fund mechanism through Afghan and international NGOs to be cosignators or references for loans from a financial institution lon the farmer associations and women's groups. The $\mathrm{NGO}$ would act as a social guarantor for the loan and be a conduit for financial services for their members. This possibility would require the NGO to reserve some funds in the case of a defalt by the farmer or women borrower.

\section{Potential Ideas}

1. Microfinance Institutions

2. NGOs

3. Gualantee Fund Mechanism

\section{Strengths}

All of ihe MFIs are pre-qualified and hat extensive experience globally with developing appropriate linamial services. MISla A will have a stapponing technical assistance componcont as part of their program which will bencfit the MFls.

The N(iOs mat already have a network within the communities to draw out potential credit worthy cliculs.

Througl a guarantec fund, a financial institution would be more apt to lend to new clients in a province. The tund could stimulate financial services to chlcrprises that may have some risk associated with them.

\section{Weaknesses}

There may be some reluctance by the MFIs to entel certain pros inces until they have demonstated the in methedologies in more populated urban setrings such as Kabul.

NGOs would need a fair ambunt of technical assistance in order lo manage a microtinanee porthitio. Generally, NCOS manage llam microcedit services under he sams operations as lher humanitarian assistance. This is not the best approich as the beneficiarien maly not understand the importances of prompt repayment.

A guarante fund would require full understanding of the proesis such that financial institutions would continue to talic eare in their da diligence of underwriting a boin to mitigate risks. 
The moribund financial system will have to be revived through the building of a stroner credit culture. It will be incumbant upon the MFls to take a tough stance about on-time loan repayments. BRAC has started paving the road in this regards with their microfinance activities in the Kabul, Balk. Nangahar and Parwin provinces. MFIs should utilize the local community leaders and district government to support their efforts in enforcing a strict repayment regime. The financial institutions could lend both short and long term to the farmers and womens groups based on their capital structure and funding sources. They could balance theil portfolio with a mix of urban and rural loans with diversificd usages. The portfolios of the MFIs shoukl imit concentrations within any economic activity. Micro financial institutions will have fo detcrmine appropriate interest rates and develop loan products which match the cash tlow cycle of agriculture production, livestock cycles and handicraft production. Also, the MFIs will have to determine if the loan usage can gencrate the cash flow necessary to service the debt. Women's resource centers could be strengthened by bringing together Afghan and international NGOs working with women. Also, the USAID gender specialist could be consulted to determine how these centers can be assisted with technical assistance and/or funding.

Although there are currently no regulations for non-bank financial institutions, MFIs gencrally do not manage their clients' savings. Some innovative methods will have to be developed to allow farmers, women, landless larmers and traders to deposit their savings in a secure institution.

It would be useful to review the interventions of previous institutions such as the Agrieullural Development Bank to determine if any of them could be incorporated into a financial institution with the goal of sustainability. This is not to advocate the resurrection of an agricultural bank. but merely a review of some lessons learned about agricultural lending in Afghanistan in past years.

Also, a review of the results of the 1FDC survey should be undertaken to decrmine the repayment rate of their fertilizer eredits. This should demonstrate the eredit discipline of the farmers. There is not a follow-on program for these farmers to receive additional credit so they may not have an incentive to repay.

Enlist the assistance of a short-term agricultural lending specialist with experience relevant for lending programs in Afghanistan to assist MFIs to develop appropriate loan products linked with the sub-sectors identified by RAMP to support.

MFIs have an opportunity to be creative and develop new ideas to deliver financial services to the growing demand in Afghanistan. While bearing in mind sustainability issues such as the transaction costs of providing the services, the pricing of services (bearing in mind if lstamic lending principles will need to be integrated into the pricing), the projecting of the demand, the outreach to the borrowers, the types of services and the methodology to cmploy in oflering loans. Bring some stabilization to the economy through access to credit.

There should be a shift from informal financial transactions, the hawala systems, to formalized transactions through financial institutions. RAMP supports the creation of a burgeoning financial intermediation market including local commercial banks, regulated microfinance banks, international financial institutions and non-bank financial institutions with extensive branch 
networks. We would expect the financial industry to be robust and provide a full-range of financial products and services including loans, savings products, foreign exchange, remittances and international money transfers.

\section{Infrastructure Rehabilitation}


REBUILDING AGRICULTURAL MARKETS IN AFGHANISTAN PROGRAM (RAMP) 


\section{ANNEX A - PERSONS CONTACTED IN KUNDUZ}

\begin{tabular}{|l|l|l|}
\hline$\#$ & Name & Title \\
\hline 1 & His Excellency Sayed M. Daud & Deputy Governor - Kunduz Province \\
\hline 2 & Haji M. Ebrahim & President of Agriculturc and Animal Husbandly \\
\hline 3 & M. Zubair & President of Irrigation - Kunduz \\
\hline 4 & Eng. Mohanmed Basim & Representative - MRRD Kunduz \\
\hline 5 & Abdul Raouf Mehraban & President - MRRD Kunduz \\
\hline 6 & Mohammed Salim & Director, Irrigation Management \\
\hline 7 & Mr. Mahboobullah & Executive Director, Governor's Office \\
\hline 8 & Abdul Wahid & Director, Governor's Office \\
\hline 9 & Dr. Naser Ahmad & Director of Veterinary Department - Kunduz \\
\hline 10 & Haji Lalmohammad & Kunduz Farmer's Center \\
\hline 11 & Abdul Ghafour & Landlord/Farmer, Chahar Dara District \\
\hline 12 & Haji Samad Baay & Farmer, Aqtash Villagc, Khan Abad District \\
\hline 13 & Assadullah Habibi & FAO/NPPP/OIC \\
\hline 14 & Ghulum Mohammed Aqtash & Director, KRA \\
\hline 15 & Eng. Mohanmed Abgal & OIC KRA Kunduz Office \\
\hline 16 & Gul Rahman & Agriculture Officer, KRA Kunduz \\
\hline 17 & Merza Mohammed & Agronomist, KRA Kunduz \\
\hline 18 & Abdul Hamid & Finance Officer, KRA Kunduz \\
\hline 19 & Noor Rahim & Wheat Trader - Khan Abad \\
\hline 20 & Zeyaullaha Khan & Wheat Market Owner - Kunduz \\
\hline 21 & Mohammed Zalmai & Wheat Mill Operator - Kunduz \\
\hline 22 & Haqi Mohammed Shah & Wheat Mill Owner - Kunduz \\
\hline 23 & Mr. Mohagug & OIC ICARDA Kunduz \\
\hline 24 & Farmers Association Reps (40) reps) & Aqtash Village, Khan Abad District \\
\hline 25 & Farmers Association (35 reps) & Wazir Village, Chahar Dara District \\
\hline & &
\end{tabular}


REBUILDING AGRICULTURAL MARKETS IN AFGHANISTAN PROGRAM (RAMP) 


\section{ANNEX B - KUNDUZ DEPUTY GOVENOR'S LETTER TO MAAH}

August 9,2003

Minister Sayed Hussain Anwari

Ministry of Agriculture and Animal Husbandry

Transitional Islamic State of Afghanistin

Kabul, Afghanistan

Excellency:

I am pleased to report that the Kunduz Market Assessment Team has visited Kunduz since August 5 to identify market development activitics for funding by the USAID-sponsored Rebuilding Alghanistun's Agricultural Markets Program (RAMP).

My staff and I were briefed on their mission on August 5 and I met with them on the evening of August 7 to review the findings of their discussions with farmers, agribusinesses, NGOs and provincial oflicials. During that meeting, I summarized the market development priorities of my provinee that should be considered for funding by RAMP. I would appreciate Your Excellency's consideration in giving Kunduz a prominent role in the RAMP program. The following areas need RAMP assistance:

1. Road Infrastructure - As the breadbasket of Afghanistan, Kunduz urgently needs RAMP assistance in building and repairing critical roads that would alleviate the bottleneck the linmers and commodity traders face in accessing the undersupplied markets around the country. (once these roads are built and repaired, the high priority irrigation projects and agricultural production and marketing interventions would provide the necessary boost in productivity that Kundur cann surely achieve. The following road projects will increase Kunduz' access to critical agrricullural markets:

- There is an urgent need to immediately repair the Kunduz-Baghlan road connecting Kunduz. and Kabul. This work is necessilly to expand outlying regions' access to Kunduz' surplus. lower-cost grain supply;

- Within the province, our highest road priority is repair of the Khan Abad and Chathar Dilra bridges; and

- We also need to repair the $40 \mathrm{~km}$. Alchin-Qala-e-zal secondary road and tertiary roids in Chahar Dara.

2. Irrigation Infrastructure - Improved irrigation systems are needed not only lor increased agricultural production, but also to protect land, homes and other assets that are lost to spring floods each year. By ensuring that canal systems can handle these floods, thousands of dolliars will be saved for Kunduz provine. The following irrigation projects will increase production of our most important crops:

- The irrigation system in Khan Abad District needs extensive rehabilitation of intakes, spillways, culverts and canals along the four subsystems of the Khan Abatd River; and

- One $60 \mathrm{~km}$. canal in the Chathar Dana District irrigation system needs cleaning and whisuing.

Both of these systems have been extensively surveyed. I believe these improvements will increase Kunduz agricultural productivity substantially. I will make my irrigattion staff avialible 
to provide RAMP the design and construction specifications that cin immediately be incorporated in job orders to qualified RAMP subcontractors.

3. Agriculture - Kunduz grain yields have increased dramatically over the past year, and h he outlook is promising for the coming rice harvest. As a result of this suceess, what prices are down to levels close to, or below the cost of production. If this production trend continues, without improved transport access to other grain deficit regions of the country, farm incentives lior further grain production will be lost. The following assistance is needed to strengthen our agricultural markets:

- Our farmers and agribusiness tradcrs need additional storage facilities for inputs (sceds, fertilizer, pesticides) and products (grains, pulses, fresh vegetables);

- Our farmers need access to credit to finance inputs, tractors and farm machincry;

- We need assistance to increase the productivity of our small ruminant livestock sib sector, including improved melicine supply; and

- There is also a critical need for cfficient input markets for agricultural inputs.

In addition to these specific agricultural development projects, we also need expanded access 10 linanee for more women's enterprises in carpet weaving, handicrafts and wool processing for textiles. Women need these income generating activities to bring additional income to their families.

I await Your Excellency's quick decision on these urgent agricultural development priorities fur Kunduz. We look forward to collaborating with RAMP to implement these projects as soon as qualificd subcontractors can be engaged.

Yours Most Sincerely,

Sayed Mohammad Daud

Deputy Governor

Kunduz Province

Kunduz, Afghanistan 
ANNEX C - SUMMARY OF PARTICIPATORY RURAL ASSESSMENT

(Projected Total for 5 Districts: Central Kunduz, Khan Abad, Iman Sahib, Charadara, and Archi)

\begin{tabular}{|c|c|c|c|c|c|c|c|c|}
\hline $\begin{array}{l}\text { 1. Agricultural Production } \\
\text { and Sates lindicalors } \\
\text { Non HW Grops }\end{array}$ & Jersos & Tons: & $\begin{array}{l}\text { Yislos } \\
\text { trgeto) }\end{array}$ & 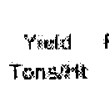 & $\begin{array}{c}\text { Farm Prige } \\
\text { falkgl }\end{array}$ & $\begin{array}{l}\text { Froductiar: } \\
\text { volue } \\
\text { at oug }\end{array}$ & 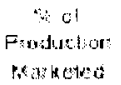 & 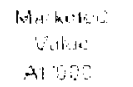 \\
\hline $\begin{array}{l}\text { Non.HW Crops } \\
\text { Jarley }\end{array}$ & $3.7 * 4$ & 2.348 & 269 & t. 35 & 7.52 & 72.053 & 45 & 85.5 \\
\hline Eutor & 48,203 & $=1.827$ & 572 & 2.86 & 13.07 & $.361,204$ & 5 & 3931 \\
\hline Atres ingers Ful & 57.623 & 25.212 & 437 & 2.19 & 3,36 & 04.745 & 71 & 50250 \\
\hline 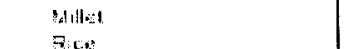 & : & - & - & - & $=$ & . & • & - \\
\hline $7 \mathrm{Cs}$ & 309,41 & .27 .503 & 465 & 2.32 & 15.00 & 2.170030 & 30 & 1.700705 \\
\hline Mwes! & 406.305 & 20.105 & 493 & 2.47 & 4,46 & 402631 & 59 & 507505 \\
\hline Total Norn-HV Crops & 690,367 & 429,198 & 48.2 & 2.41 & 8.53 & $3,650,63.2$ & 75 & 2.149 .531 \\
\hline 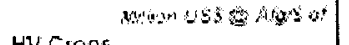 & 48.00 & & & & & 78.263 & & 57.116 \\
\hline $\begin{array}{l}\text { HV Crops } \\
\text { Vegetables }\end{array}$ & & & & & . & & & \\
\hline Ex: FIolen: & 10.207 & 3120 & 597 & 2.90 & 14.05 & 58.223 & 59 & 5051 \\
\hline Eoan (atho ugg) & $\dot{.}$ & & 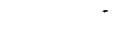 & - & - & - & & - \\
\hline 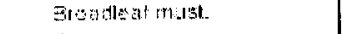 & + & - & - & - & $\cdot$ & " & - & $\cdot$ \\
\hline Cabuage & - & $\cdot$ & - & - & - & & $\cdot$ & + \\
\hline Coltijlawar & $\stackrel{-}{-}$ & $\cdot$ & $\dot{-}$ & - & - & . & 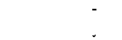 & - \\
\hline Ont: & 2048 & $-x$ & 18.2 & 906 & 0.98 & 33.335 & 20 & 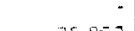 \\
\hline Sulinter & 2.849 & 3.72 & 1.812 & $\begin{array}{l}9.06 \\
3.09\end{array}$ & $\begin{array}{l}8.98 \\
5.14\end{array}$ & $\begin{array}{l}32.335 \\
23.680\end{array}$ & 70 & $=857$ \\
\hline Egplan & $\begin{array}{r}2.840 \\
110\end{array}$ & 4.1509 & 1.618 & $\begin{array}{l}8.08 \\
5.70\end{array}$ & $\begin{array}{r}5.14 \\
445.42\end{array}$ & $\begin{array}{l}23.680 \\
50.500\end{array}$ & 41 & 191802 \\
\hline Gillo & . & 126 & 1. 140 & 5.70 & $\begin{array}{r}445.42 \\
-\end{array}$ & $50.0 \mathrm{Co}$ & 58 & 4900 \\
\hline Sirleg & - & 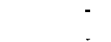 & - & - & - & • & - & $\cdot$ \\
\hline 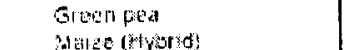 & - & - & $\cdot$ & $\dot{*}$ & $\dot{-}$ & $\dot{.}$ & $\cdot$ & $\cdot$ \\
\hline 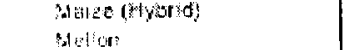 & 44.245 & 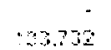 & - & 1500 & 168 & 225305 & - & $\cdot$ \\
\hline 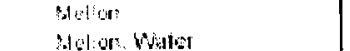 & 33.752 & 0.732 & 3,015 & $\begin{array}{l}15.08 \\
14.76\end{array}$ & $\begin{array}{l}1.68 \\
1.77\end{array}$ & & 53 & 3070 \\
\hline stal on Wator & & $\$ 4450$ & 2.951 & & $\begin{array}{l}1.7 \% \\
3.60\end{array}$ & 170.200 & 59 & 15065 \\
\hline Shri:s & 5.728 & $7 \approx 1$ & 389 & $\begin{array}{r}4.94 \\
10.09\end{array}$ & $\begin{array}{l}3.60 \\
3.65\end{array}$ & 20.504 & 78 & 7025 \\
\hline Onim & 2.185 & 1.554 & 2019 & $\begin{array}{r}10.09 \\
6.31\end{array}$ & $\begin{array}{r}3.66 \\
11.15\end{array}$ & 42.322 & 84 & 5515 \\
\hline Otf 10uly & 3.145 & $\therefore 450$ & 1.252 & $\begin{array}{r}6.31 \\
1020\end{array}$ & $\begin{array}{r}11.15 \\
5.34\end{array}$ & $: 5,480$ & 90 & 14.730 \\
\hline Fatala & 2,105 & 5.454 & 2.052 & $\begin{array}{r}102 \mathrm{ZS} \\
6.11\end{array}$ & 5.34 & 34.545 & 157 & 23157 \\
\hline Pusmakn & $\begin{array}{r}2.135 \\
231\end{array}$ & 2574 & 1.223 & $\begin{array}{r}6.81 \\
14.65\end{array}$ & 9.02 & 20.22 & 52 & 121043 \\
\hline Aasint: & $\begin{array}{r}231 \\
10.952\end{array}$ & 652 & 2.931 & 14.65 & 18.67 & 5,018 & $\$ 1$ & 14. \\
\hline Tornto & $\begin{array}{r}10.952 \\
5.050\end{array}$ & $1 \div .601$ & 1.0065 & 5.32 & 1.75 & 20.446 & 73 & 140.08 \\
\hline Earrot & $\begin{array}{l}5.050 \\
1.357\end{array}$ & 5855 & 3451 & 15.31 & 4.52 & $2 \mathrm{a} .303$ & 93 & 24.273 \\
\hline Tunso & & 2050 & 1.730 & B. & 5.23 & 13.811 & 93 & 12916 \\
\hline Ingror & $\begin{array}{r}10.369 \\
5.008\end{array}$ & $19 \pi 8$ & 857 & 0.93 & $\$ 43$ & $: 0.514$ & 77 & 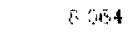 \\
\hline$C_{1}$ & $\begin{array}{r}5.028 \\
42\end{array}$ & .071 & 210 & 1.05 & 1.37 & 1.470 & 58 & 855 \\
\hline$=\sin N$ NL: & & 15 & 448 & 2.24 & 0.00 & $15 \%$ & 50 & $\because$ \\
\hline 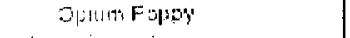 & . & - & $\cdot$ & - & - & $\cdot$ & . & - \\
\hline $\begin{array}{l}\text { Legumes } \\
\text { Buzk:kg; }\end{array}$ & $\cdot$ & - & - & - & . & - & - & 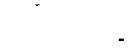 \\
\hline Sllirgy Bear & 357.574 & 22,200 & 204 & 102 & 10.25 & $330 . \pm 01$ & 54 & 10192 \\
\hline e.tsl & - & $\cdot$ & - & - & - &. & - & - \\
\hline Onikpa & 60 & 14 & 223 & 1.35 & 7.00 & 32 & 82 & 30 \\
\hline Styosar & $\begin{array}{l}- \\
-\end{array}$ & - & - & - & - & $\cdot$ & $\sim$ & - \\
\hline Edble a s & 0.282 & & & - & $\therefore$ & & & \\
\hline 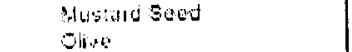 & 0.282 & +505 & 52 & 0.01 & $\begin{array}{r}10.83 \\
-\end{array}$ & 25,334 & 83 & 21.122 \\
\hline $\begin{array}{l}\text { Shing } \\
\text { Salllowes }\end{array}$ & $10,36]^{-}$ & $\cdot$ & - & - & 11.05 & - & - & $20-8$ \\
\hline $\begin{array}{l}\text { Salllowed } \\
\text { Sulllowe }\end{array}$ & $\begin{array}{r}10,363 \\
555\end{array}$ & 7448 & 235 & 1.88 & $\begin{array}{l}11.05 \\
1200\end{array}$ & 27044 & 47 & 12758 \\
\hline $\begin{array}{l}\text { Sollowe } \\
\text { Fruits }\end{array}$ & 505 & 121 & 240 & 1.20 & 12.00 & $1,45 i$ & 80 & 1.85 \\
\hline $\begin{array}{l}\text { Fiuits } \\
\qquad \text { mpate }\end{array}$ & 94 & & & & 2380 & & & \\
\hline 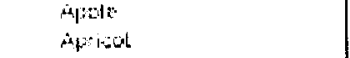 & 36 & $4: 3$ & 4.405 & $\begin{array}{r}22.02 \\
-\end{array}$ & $\begin{array}{r}2380 \\
-\end{array}$ & $\begin{array}{r}955 \\
-\end{array}$ & 20 & . 2820 \\
\hline $\begin{array}{l}\text { Antrot } \\
\text { Cnety }\end{array}$ & - & - & - & - & - & - & + & . \\
\hline $\begin{array}{l}\text { Goetty } \\
\text { Grape, Fitesh }\end{array}$ & $41: 5$ & 12.150 & 2055 & 14.7 & 12.00 & $140.85 i$ & 75 & $111.0150^{\circ}$ \\
\hline Siape. Pallsin & - & $\begin{array}{r}12.750 \\
-\end{array}$ & $\begin{array}{r}6.000 \\
-\end{array}$ & - & - & $\begin{array}{r}140.001 \\
.\end{array}$ & - & $\begin{array}{r}111.0130 \\
-\end{array}$ \\
\hline slusetry & 24 & 30 & 1.647 & 823 & - & - & - & - \\
\hline Fenet & 979 & 2442 & 2.494 & 12.4 & 7.16 & 7.482 & 91 & 14.212 \\
\hline Parar & 192 & 5.35 & 5.531 & 28.15 & 7.90 & 4.503 & 95 & 4.35 \\
\hline PR:II & 457 & 958 & 4.303 & 21.52 & 8.44 & 10.500 & 84 & 14005 \\
\hline Fonogranc: & - & & $\cdot$ & - & - & - & - & - \\
\hline $\begin{array}{l}\text { Nuts } \\
\text { inl: or ol }\end{array}$ & & & $299^{\circ}$ & & 1803 & 890 त3 & 92 & 84 \\
\hline 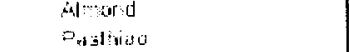 & $\begin{array}{l}3.350 \\
435\end{array}$ & $1,0$. & $\begin{aligned} 201 \\
-\end{aligned}$ & $\begin{array}{r}1048 \\
-\end{array}$ & 19.0.5 & 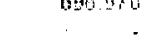 & P & 04181 \\
\hline 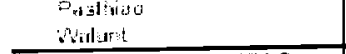 & $\begin{array}{l}422 \\
1 \leq 1\end{array}$ & 193 & 1.400 & 7.00 & 2800 & 5313 & 90 & 9.7 .31 \\
\hline Total HV Crop & 326,328 & 354.540 & 1,086 & 5.44 & 3.98 & 1.411 .860 & 84 & 1.183 .195 \\
\hline wongn bs 3 . & $48.0 C$ & & & & & 29.414 & & 24650 \\
\hline
\end{tabular}


Annex C - Summary of Participatory Rural Assessment (continued)

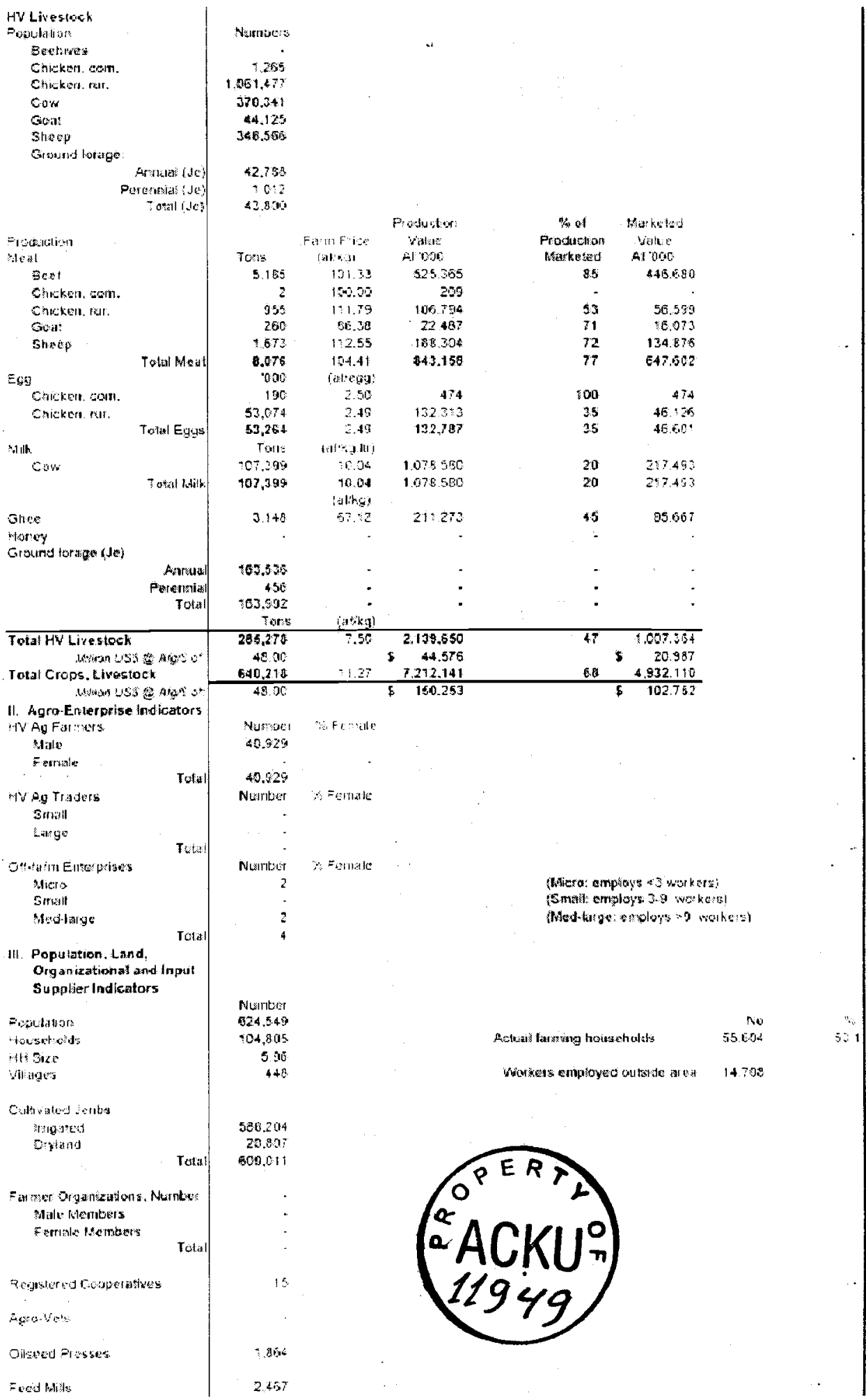

